\title{
SUBSTANCE P INCREASES IN VITRO LYMPHOKINE-ACTIVATED- KILLLER (LAK) CELL CYTOTOXICITY AGAINST FRESH COLORECTAL CANCER CELLS.
}

\author{
by: Hélène Flageole \\ from: Department of Surgery \\ Montreal General Hospital \\ McGill University, Montreal
}

November 1992

A thesis submitted to the Faculty of Graduate Studies and Research in partial fulfillment of the requirements of the degree of Master of Science. 


\title{
SUBSTANCE P INCREASES LYMPIOCYTE CYTOTOXICITY AGAINST COLONCANCER.
}

\author{
by: Hélène Flageole
}

\author{
from: Department of Surgery \\ Montreal General Ilospital \\ McGill University, Montreal
}

November 1992

A thesis submitted to the Faculty of Graduate Studies and Research in partial fulfillment of the requirements of the degree of Master of Science. 


\section{TABLE OF CONTENTS}

ABSTR $\triangle C T$

RISSUME

INTRODUCCTION

A- Colorectal cancer: Conventional adjuvant therapy

B- Immunotherapy in colorectal cancer

1 - Background

2- Active immunotherapy

3- Monoclonal Antibodies

4- Adoptive Immunotherapy

C- The problems of colorectal cancer

D- IIormonal manipulation

E- Purpose

\section{MATERIALS AND METIIODS}

A- Patient population

B- Isolation and purification of gut mucosal lymphocytes (GML)

C- Induction of LAK cell activity from GML

D- IIormonal enhancement of GML

E- Isolation of fresh colorectal cancer cells

F- Target cell lines

G- Radioactive labeling of target cell lines

11- Microcytotoxicity assaly for LAK cell activity

\section{RESULTS}

A- LAK compared to LAK + SP against HT-29

B - LAK compared to LAK + SP against fresh colon cancer

C- Comparison of activity of LAK + SP against HT-29 and fresh colon cancer cells

\section{DISCUSSION}

\section{BIBLIOGRAPHY}




\section{ABSTRAC'T}

Gut associated lymphoid cells are modulated by gut hormones. We postulated that lymphokine-associated-killer (LAK) cell cytotoxicity of lymphocytes from the gut mucosa may be increased by substance $P(S P)$.

Intestinal lamina propria mononuslear cells (LPMC) and colonic cancer cells were isolated from operative specimens by mechanical and enzymatic dissociation methods. Eiffector LAK celis were induced by culturing LPMC with $250 \mathrm{u} / \mathrm{ml}$ of recombinant interleukin-2 (IL-2). Substance $P\left(10^{-5} \mathrm{M}\right)$ was added to the culture. Targets consisted of fresh colon cancer cells, HT-29 and control cell lines. After 4 days of incubation, cytotoxicity was measured using a 4-hour ${ }^{51} \mathrm{Cr}$ release assay.

LAK cells showed moderate cytoloxicity against IIT-29) and none against fresh colon cancer cells. LAK cells + substance P showed moderate cytotoxicity against IIT-29 and strong cytotoxicily against fresh cancer cells. Cytotoxicity \pm SEM at various effector-totarget (E:T) ratios was: (* denotes $\mathrm{p}<0.05$ compared with above).

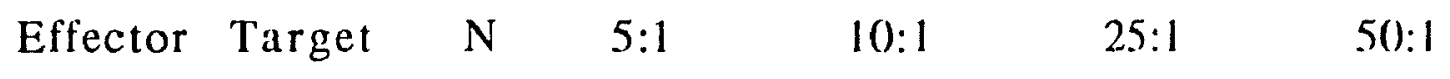

$\begin{array}{lllllll}\text { LAK } & \text { HT }-29 & 7 & 2.8 \pm 0.5 & 11.6 \pm 1.0 & 12.3 \pm 2.3 & 17.8 \pm 4.2\end{array}$

$\begin{array}{lllllll}\mathrm{LAK}+\mathrm{SP} & \mathrm{HT}-29 & 11 & 1.2 \pm 0.5 & 4.1 \pm 0.9 & 9.3 \pm 1.0 & 16.9 \pm 3.1\end{array}$

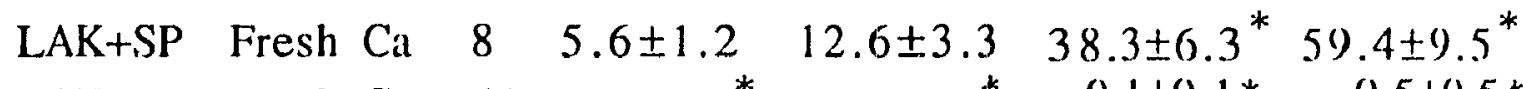

$\begin{array}{llllll}\text { LAK Fresh Ca } & 11 & 0.0 \pm 0.0^{*} & 0.1 \pm 0.1^{*} & 0.1 \pm 0.1 * & 0.5 \pm(0.5 *\end{array}$

Substance $P$ significantly increases LAK cell cylotoxicity against fresh colon cancer cells, but not against cultured cells. 


\section{RESUME}

Les lymphocytes intestinaux sont influencés par les hormones intestinales. Nous avons postulé que la cytotoxicité des cellules LAK (lymphokıne-activated-killer) de l'intestin pouvait être augmentée par la substance P (SP).

Nous avons isolé des LPMC (lamina propria mononuclear cells) et des cellules de cancer du colon provenant des spécimens opératoires par une méthode enzymatique et mécanique. Les cellules LAK furent induites en cultivant les LPMC avec $250 \mathrm{u} / \mathrm{ml} \mathrm{d}$ II,-2 (interleukin-2). Une concentration de $10^{-5}$ de substance $P$ fut ajouté au tnédium de culture. Comme cibles nous avons utilisé des cellules du cancer du colon fraîches, HT-29 (une lignée de cellules cancéreuses humaines gardées en culture); et une lignée de contrôle. Après 4 jours d'incubation, nous avons mesuré la cytotoxicité à l'aide d'un "5I $\mathrm{Cr}$ release assay" de 4 heures.

Les cellules LAK démontrèrent une cytotoxicité inodérée contre IIT-29 et aucune envers les cellules cancéreuses fraîches. Les cellules LAK cultivées avec de la substance $P$ ont démontré de nouveau une cytotoxicité modérée contre HT-29 mais cette fois la cytotoxicité envers les cellules fraîches était forte. Le pourcentage de cytotoxicité \pm SEM à divers ratios de cellules fut: (* indique $\mathrm{p}<0.05$ comparé à la ligne du dessus).

$\begin{array}{llllll}\text { Cellules Cible } & \mathrm{N} & 5: 1 & 10: 1 & 25: 1 & 50: 1\end{array}$

$\begin{array}{lllllll}\text { LAK } & \text { IIT }-29 & 7 & 2.8 \pm 0.5 & 11.6 \pm 1.0 & 12.3 \pm 2.3 & 17.8 \pm 4.2\end{array}$ $\begin{array}{lllllll}\text { LAK }+ \text { SP } & \text { HT }-29 & 11 & 1.2 \pm 0.5 & 4.1 \pm 0.9 & 9.3 \pm 1.0 & 16.9 \pm 3.1\end{array}$ $\mathrm{LAK}+\mathrm{SP}$ Fresh Ca $8 \quad 5.6 \pm 1.2 \quad 12.6 \pm 3.3 \quad 38.3 \pm 6.3 * 59.4 \pm 9.5^{*}$ LAK Fresh Ca $110.0 \pm 0.0^{*} \quad 0.1 \pm 0.1^{*} \quad 0.1 \pm 0.1^{*} \quad 0.5 \pm 0.5^{*}$

Nous concluons que la substance $P$ augmente de façon significative la cytotoxicité des cellules LAK contre les cellules de cancer du colon fraîches mais pas celles gardées en culture. 


\section{INTRODUCTION}

Colon carcinoma is a devastating disease. In North American males, it is only preceded by lung cancer as a cause of cancer death; in North American females it is the third cause of cancer death after lung and breast cancers. ${ }^{1}$ Colon cancer is responsible for $20 \%$ of all cancer deaths. ${ }^{1}$ To this day, the only curative therapy consists of definitive surgery with removal of all malignant tissue including isolated metastatic disease.

Because it is such a prevalent and lethal disease, it is important to identify patients with pre-malignant lesions or carly disease. Despite all the efforts being deployed to diagnose colorectal cancer early in the hope of curative surgery, the majority of calses are diagnosed once the disease has already become invasive. This may explain the failure to improve survival rates for colorectal cancer in the last thirty years. ${ }^{2}$ In addation, $50 \%$ of patients having surgery with curative intent will have a recurrence within 5 years and most patients undergoing a second resection will die of their disease. ${ }^{2}$

Adjuvant therapy is administered in addition to surgical treatment to the primary colorectal cancer with the intent to improve outcome. It is normally given to patients who have discase extending beyond the margins of surgical resection. It can be given to both patients with advanced local disease and metastatic disease. 60 There are several forms of adjuvant therapy: the more conventional modalities include radiotherapy and chemotherapy; the more innovative and experimental tools consist of hormonal manipulation and immunotherapy. 
A- COLORECTAL CANCER: CONVENTIONAL ADJUVANT THERAPY (Radiotherany, Chemotherapy and hormone therapy)

Individual adjuvant treatment modalities are selected for precise indications and each has its limitations.

Radiation has been found to be an effective treatment in the local and regional control of cancers in the colon and rectum. It is relevant to both large bowel and rectal carcinomas as local recurrence is an important cause of morbidity and mortality in both these diseases. ${ }^{3}$ Cass evaluated 165 patients with locally recurrent cancer. ${ }^{4}$ Sixty-three had local recurrence alone, 15 had distant metastasis to the liver and $92 \%$ of the local recurrences developed in contiguous structure of the original tumor. Any form of treatment that is addressing local control is therefore very valuable. Radiation alone can be used to treat rectal cancer fixed to pelvic structures or for palliation for locally inoperable cancer. ${ }^{3}$ There is evidence that pre-operative radiation therapy may decrease the rate of local recurrence. 2,3 Unfortunately, the dosage that can be administered is restricted by the many structures in the abdomen that have a limited tolerance to radiation, particularly the small bowel. Chemotherapy and radiotherapy combined seem to be more effective in reducing overall and local recurrence than radiation alone. ${ }^{3}$

Chemotherapy has been applied most often in the context of systemic therapy for metastatic disease or as adjuvant therapy after resection of a primary tumor. 5 The standard chemotherapeutic agents available for the treatment of colorectal cancer are 5-FU and leucovorin. 5.60 The cytotoxicity of 5-FU can be augmented by leucovorin.5 It allows to obtain a desired effect using a lower dose of 5-FU thus minimizing its toxicity. which is primarily myelosuppression. 5

Historically, response rates in the treatment of disseminated disease have been less than 20\%. Recently several studies have been conducted suggesting that more intensive treatment regimens yield higher response rates. 5 Combination of methotrexate plus 5-FU and 
cisplastin pius 5-FU have been tried but the results are not superior to 5-FU alone. ${ }^{5}$ A trial was done to assess the efficaley of 5-1:l and levamisole. Results showed a clear benefit.6 This combuaton is effective in prolonging relapse-free and overall survival.o()

Nonetheless, $40 \%$ of patients treated with this regmen wall relapse 7

For patients with isolated hepatic metastases, mtra-artertal hepatic infusion of 5-FU has shown a higher response ratc and prolonged survival compared with systemic admintstration.2.5 However, toxicity remains a significant problem. Portai vein infusion has also been attempted and is much less effective than hepatic artery infusion. 5

5-FU is a radiosensitizer explaining the better results when the two modaliries are combined.3,5 As an adjuvant modality. chemotherapy with 5-FU or combination of several agents brullgs al best a modest increase in survival for colon cancer. Rectal cancer on the other hand, is much more clearly sensitive to adjuvant therapy and this latter form of treatment is clearly indicated for rectal disease. 5 This discrepancy in response 10 treatment is best explained by the fact that colon and rectal cancers are two different diseases despite the fact that they are often discussed rogether.

Colon cancer, because of the anatomy, presents lisually lattle difficulty in achieving complete removal of the primary tumor. (On the other hand, because of the confines of the pelvis, rectal cancer spreads to the lateral pelvic walls rapidly such that surgically resecting all local disease is more difficult. In this seltung, aljuvant therapy can be very usefui.

In summary, neither radiotherapy nor chemotherapy, alone or in combination, is currently successful at curing colorectal cancer. They cannot be depended upon when surgery is not possible or has failed; neither is successful in prolonging life significantly. While the effort to develop new chemotherapeutic agents and to optimise the doses and modes of delivery of radiation is still ongonng, new and different modalities are being actively explored. 
Hormonal manipulation is a budding field which rests on in vitro and in vivo observations in/on experimental animals, that some hormones and growth factors promote tumor growth and proliferation. ${ }^{8}$ Clinical applications are used daily in the treatment of breast and prostatic cancer. Some breast cancers are dependant on ovarian hormones for giowth. ${ }^{9}$ Women whose primary tumor is estrogen-receptor-positive respond to anti-estrogen therapy. The nonsterndal antuestrogen tamoxifen is the endocrine treatment of choice for breast cancer. ${ }^{10}$ Trials have shown a disease-free and overall survival advantage at 5 years for patients with estrogenreceptor-positive primary tumors after 3 years of tamoxifen. ${ }^{11}$ Similarly prostatic cancer is dependant on androgens for growth. ${ }^{12}$ But in contrast to breast cancer, the correlation between androgen receptor status of the prostatic tumor and hormonal therapy is not well established 13,14 Anti-androgen therapy for prostatic cancer is nonetheless effective and several methods are available: surgical castration; medica! castration with estrogens; LIIRII agonists or ketoconazole; androgen-receptor antagonists such as flutamide. ${ }^{2}$ Work is also being done in the field of colorectal cancer with substances like gastrin. ${ }^{8}$ Gastrin promotes the growth of some gastric and colonic carcinomas in vitro. ${ }^{15}$ Gastrin acts by binding to specific surface receptors which have been demonstrated on cancer cells from human colon. ${ }^{16}$ Hormonal manipulation through gastrin receptor antagonism as a viable therapeutic tool awaits further experimentation. 8

\section{B- IMMUNOTHIERAPY IN COLORECTAL CANCER}

\section{1-BACKGROUND}

Immunity plays a central role in defense against cancer. Immunotherapy is based on the theory that a tumor is allowed to proliferate because it has escaped immune surveillance. To be recognized and eliminated, a tumor cell must be considered "non$s^{\prime} l f^{\prime \prime}$ by the immune system. If the characteristics of the tumor change and become "self", it will no longer be challenged by the 
immune system. Another possibility is that the tumor estapes immune surveilance because the immunc system is suppressed. The site of suppression could be at the level of tumor recogntion on in response to it. Immunotherapy is therefore based on the premses that our body's immune system can be stmmulated or mampulated out of supression to eradicate residual local disease alter surgical resection or widespread metastatic discalse. Interest in immunotherapy was renewed in the past decade because of major technologic advances in immunology and molecular brology that have facilitated the identification, isolation and large-scale production of substances that may enhance the immune response (o) tumor. ${ }^{17}$

Several basic differences distingussh and separate immunotherapy from the more conventional treatment options. Radiotherapy and chemotherapy kill tumor cells in a log mode i.e they always kill a fraction of the tumor mass. They can never eradicate the entire tumor burden even if it is small. This mechanism of action does not apply to immunotherapy as all tumor cells could theoretically be destroyed. Practically, the tumor burden would have to be small enough to allow immune effector cells to make contact with all tumor cells. ${ }^{18}$ There is heterogeneity of lumor cells in the same patient and tumor cells develop resistance against chemotherapeutic drugs. Immunotherapy has the potenilal 10 circumvent these issues. ${ }^{19}$

\section{2- ACTIVE IMMUNOTHERAPY}

The concept of active specific immunotherapy dates from the 1960's. The rationale for active specific immunotherapy is based on the premise that immunization with unique protens on the tumor cell surface will elicit a host immune response that results in lsthality for the tumor cells but spares normal tissuc. ${ }^{20}$ The maior limitation rests with weakly immunogenic tumors: colorectal cancer is one of those. ${ }^{21}$ To circumvent this problem, adjuvants such as Bacillus Calmette-Guerin (BCG) or Corynehacterum parvum were 
employed in the hope that general immune stimulation would concomitantly increase the host anti-tumor response. ${ }^{19}$ Clinical attempts were insuccessful and have been largely abandoned. 22 The current focus of active specific immunotherapy for colorectal cancer is to use potent allogeneic or generic vaccines to tumorassociated antigens (TAA) common to most colorectal tumors. The main challenge with this approach is to identify these common tumor-assoctated antigens and to prepare potent vaccines that recognize them. A phase I trial has shown a median survival of 57 months in 28 patients, including 9 with widespread metastatic disease. ${ }^{23}$ Fivc of those 9 patients survived over 5 years. ${ }^{23}$ These results are encouraging when compared with the overall 5-year survival of $1-2 \%$ reported for patients with metastatic colon cancer. 24

\section{3-MONOCLONAL ANTIBODIES}

Monoilonal antibodies (MoAbs) hold a great deal of promise in the treatment of cancer because of their high degree of specificity compare $d$ with chemotherapy. The most widely studied MoAb in colore:tal cancer is the murine MoAb 17-1A, an immunoglobulin (Ig) $\mathrm{C}$ 2a molecule that recognizes a TAA (CO17-1A) expressed by virtually all colorectal carcinoma cells. Unfortunately, objective response rates have generally been low (around 5\%) with generally short duration of response and few complete responses. 23 Because of their high degree of specificity, MoAbs can be linked to potent toxins that either could not be employed systemically or that have potent short-range activity. Examples include conjugates with radiopharmaceuticals, chemotherapeutic agents, and immunotoxins.

\section{4-ADOPTIVE IMMUNOTHERAPY}

Adoptive immunotherapy is defined as the transfer to the tumor-bearing host of active immunologic reagents, such as cells, with anti-tumor reactivity. 21 These reagents can mediate antitumor effects directly or indirectly. ${ }^{21}$ Because the body's defense 
against malignant processes seem to rely primarily on the cellmediated arm of the immune system, the agents transferred to the host have mainly consisted of $\mathrm{T}$ cells. 17 The definte advantages of adoptive immunotherapy are that the immunosuppression gencrally associated with the tumor bearing state is not a problem; since the transferred reagents are immunologically specific. this treatment should have a high degree of specificity and consequently a low morbidity; no immunosuppression should be caused by this treatment. ${ }^{17}$ There are two limitations to adoptive immunotherapy: first a large number of cells are required for transfer; and second, there is great difficulty in generating specific immunc cells against all tumors. 17

The cornerstone of adoptive immunotherapy has been the lymphokine-activated-killer cell (LAK cell). It is one of the three type of cytotoxic $T$ cells. The other two are the cytotoxic $T$ cell and the NK (natural killer) cell. The former is Class I MHC restricted.

LAK cells are $T$ cells that become activated in the presence of interleukin-2 (IL-2). LAK cells are not MIC restricted nor restricted to a specific tumor type. ${ }^{17}$ IL-2 is a 15000 daltons glycoprolein secreted by activated $T$ cells. It was initially termed "T-cell growth factor" because of its ability to sustain the proliferation of activalted $\mathrm{T}$ cells in long term cultures. Recently its gene has been cloned and large quantities of the recombinant product are now available. IL,-2 induces or enhances the secretion of other cytokines including interferon alpha, hematopoietic colony-stimulating factors, interleukin-1, tumor necrosis factor (TNF), and B-cell growth factor. 17

Rosenberg et al. at $\mathrm{NIH}$ are responsible for much of the pioneer work with LAK cells and IL-2. Numerous studics have been done in animals, mainly in the mouse model. Several murine tumor lines have been used, in sluding a series of variably immunogenic methylcholanthrene (MCA)-induced sarcomas. Inoculation of a few sarcoma cells into a mouse's tail vein results in pulmonary, hepatic, and peritoneal metastatic lesions at 3 days, which are grossly visible at 10 days. 17 LAK cells infused alone were largely ineffective 
against 3-day and 10-day metastatic lesions, but the coadministration of LAK cells and IL-2 resulted in a dramatic reduction in tumor nodules in the lungs and livers of these animals. 25-27 Several clinical trials have also been conducted in humans. They have shown that the administration of LAK cells alone was not effective in humans. 17 Other trials were done with IL-2 alone: in the first trial with high-dose IL-2,28 10 patients were treated, and 3 of 6 patients with melanoma had a partial response, defined as a $50 \%$ or greater reduction in tumor burden. This result led to trials of high-dose IL-2 in combination with LAK cells. Several nonrandomized and randomized trials of IL-2 alone or in combination with LAK cells were done at the National Cancer Institute (Table 1). ${ }^{29}$ The overall response rates, defined as complete and partial responses, were $21 \%$ and $16 \%$, respectively. ${ }^{17,30}$ Most responses occured in patients with renal cell carcinoma and melanoma. ${ }^{17,29,30,31,32,33}$ IL-2 alone was not as effective as the combination of IL-2 and LAK cells. 17,29,30,33

Colon cancer exhibits a minimal response to these highly competent immune cells.29,34,35 
TABLE 1.-Results of Nonrandomized and Randomized trials of Interleuhin-2 (IL-2) Alone or in Combination with Lymphokune-Activated-Killer (LAK) Cells in Patients with various lypes of Cancer ${ }^{29}$

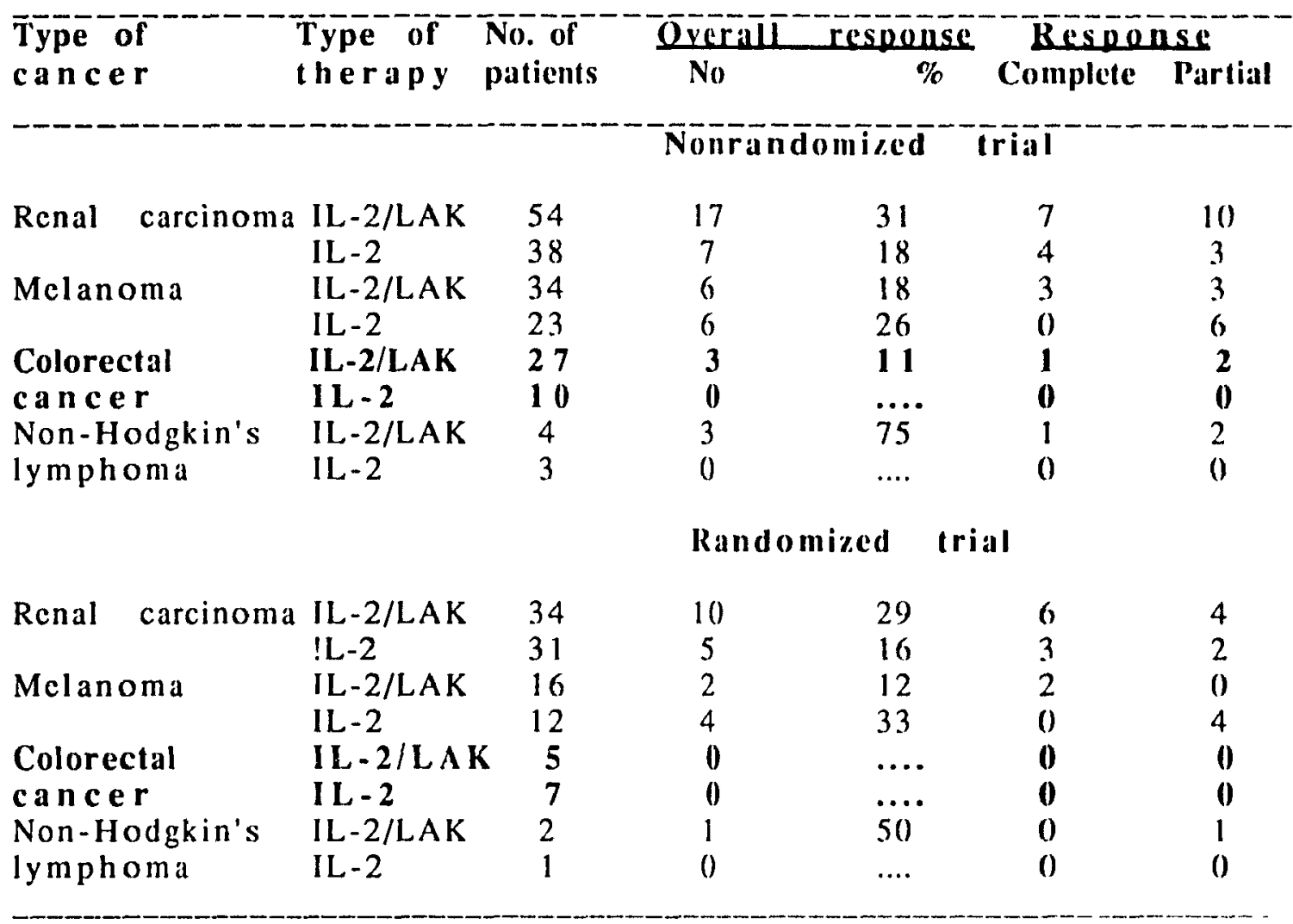




\section{C- THE PROBLEMS OF COLORECTAL CANCER}

Why is colon cancer resistant to immunotherapy with LAK cells? Three hypothess have been formulated. Firstly, this could be due to poor interaction between LAK cells and their colonic targets. Most clinical studies utilized lymphocytes isolated from the circulation to generate $L A K$ cells. Trudel et al. ${ }^{36}$ postulated that lymphocytes from the intestinal lamina propria could represent a more relcvant source of immune cells. Colon cancer cells turned out to be as resistant to lysis by lymphocytes from an intestinal source at they had been to lymphocytes isolated from the circulation. 36 Secondly, colon cancer could be resistant to LAK cell therapy because of intrinsic tumor resistance. Unfortunately, tumor dynamics are not well enough understond at the present time to allow their modification. Thirdly, the lack of response could be attributable to insufficient LAK cell cytotoxicity. This can be modulated and it constitutes the basis of this thesis.

\section{D- IIORMONAL MODULATION}

Gut-associated lymphoid cells and circulating immune cells are modified by several peptides originally described as neurotransmitters or gut hormones. ${ }^{37,38}$ This opens the possibility of using hormonal manipulation to improve LAK cell cytotoxicity against colon vancer. Although the exact mechanism through which neuropeptides and gut hormones modify the immune function is not entirely understood, several facts have been documented.

Somatostatin (SMS) inhibits lymphocyte proliferation and stimulates antibody-dependant cellular cytotoxicity in-vitro. 39,40 Substance $P$ stimulates human $T$ lymphocyte proliferation in-vitro. $41 \quad B$ endorphins enhance the proliferative response of $T$ lymphocytes and stimulate chemotaxis in monocytes and neutrophils. 42,43 The presence of high-affinity hormonal receptors on lymphocytes suggests the possibility that modulation of gut mucosal immunity can be achieved via a direct effect on lymphocytes. A subset of lymphocytes has been shown to possess high-affinity receptors for 
substance P; SMS receptors have been identified on peripheral blood iymphocytes; and $B$-endorphins are known to exert their action through surface receptors. $44,45,46,47$ Although further investigations are required to clarify the nature of hormone-immune cell interactions, their existence is no longer questioned.

\section{E- PURPOSE}

The purpose of our project was to attempt to modulate gut mucosal immunity with various gut hormones. We used lymphocytes isolated from the intestinal lamina propria and attempted to augment their cytotoxicity. There are over thirty hormones which have effects on the gut. We have chosen to study substance $P$, becalse its effect on non-intestinal immune cells is well documented. $41,42,43$ Gut lymphocytes carry surface receptors for this hormone. 45 The mere presence of surface receptors for these hormones on gut lymphocytes strongly suggests that they do in fact play a role. This project will help shed some light on the effects of gut hormones on gut mucosal immunity. If hormonal modulation of gut mucosal immunity is a viable hypothesis, this could open a new exciting avenue for adoptive immunotherapy in the treatment of colorectal cancer. 
MATERIALS AND METHODS

\section{A- PATIENT POPULATION}

Freshly resected intestinal tissue was obtained from operative specimens of patients undergoing bowel resection for cancer or benign colonic conditions at the Montreal General Hospital, the Royal Victoria Ilospital and St-Mary's Hospital. An agreement was made with the respective Departments of Pathology to ensure that the needs for tissue did not interfere with staging of the tumor in any way.

Lamina propria mononuclear cells (LPMC) were isolated from 19 patients. Ten of them had colorectal cancer: 5 had sigmoid lesions, 3 had rectal lesions and 2 had cecal tumors. Three patients had surgery for excision of a villous tumor or multiple polyps, 3 had diverticular disease, 1 had Crohn's disease, 1 had ulcerative colitis and 1 had intractable lower gastrointestinal hemorrhage. The patients who were operated on for cancer also had part of the resected specimen utilized for isolation of fresh cancer cells.

\section{B-ISOLATION AND PURIFICATION OF GUT MUCOSAL LYMPIOCYTES (GML)}

Gut mucosal lymphocytes (GML) were isolated using Fiocchi's modification 48 of the original technique described by Bull and Bookman.49 The mucosa was dissected from the rest of the bowel wall and cut in fragments measuring approximately $1 \mathrm{~cm}^{2}$. The fragments were freed of mucus and epithelial cells in sequential steps, using $75 \mathrm{mg}$ of dithiothreitol (DTT; Sigma Chemical Co., StLouis MO) in $50 \mathrm{mll}$ of calcium and magnesium free Hank's balanced salt solution (CMF-HBSS; GIBCO) for thirty minutes and $37,5 \mathrm{mg}$ of ethylenediaminetetratee ic acid (EDTA: Sigma) in $90 \mathrm{ml}$ of CMFHBSS for two periods of ninety minutes. Overnight digestion in calcium and magnesium free Hank's balanced salt solution (CMFIIBSS) containing $0.01 \%$ collagenase and $0,01 \%$ deoxyribonuclease (both from Worthington Diagnostic system, Inc., Freehold NJ) was 
performed. The resulting crude cell suspension was filtered and purified over a Ficoll-Hypaque gradient (Pharmacia). The isolated cells were almost exclusively LPMC (90-95\% purity, verified by microscopic examination).

\section{C-INDUCTION OF LAK CELL ACTIVITY FROM GML}

Cells designated for induction of LAK cells were put in RPMI1640 culture medium (GIBCO) with $10 \%$ human $\mathrm{AB}$ serum (GIBCO), $1.5 \%$ Hepes buffer (GIBCO), 1\% gentamicin, $2.5 \%$ peniclllinstreptomycin-fungizone (PSF, GIBCO). Recombinant human IL,-2 (Cetus Corporation, Belmont $\mathrm{CA}$ ) was added at a concentration of 250 units $/ \mathrm{ml}$. The cells were cultured at a concentration of $0.5 \times 10^{6} / \mathrm{ml}$ in upright tissue culture flasks at $37^{\circ} \mathrm{C}$ in a $5 \% \mathrm{CO}_{2}-95 \%$ humidified air atmesphere for a period of 4 days. In order to establish that the cells resulting from this culture were indeed LAk cells, we lirst cultured the intestinal lymphocytes without IL-2. When an assay was done against K562 and Daudi, K562 was sensitive to these lymphocytes whereas Daudi was resistant. Then the gut lymphocytes were cultured with IL-2 as described above. Repeat assays indicated that these cells could kill both K562 and Daudi establishing that they were indeed LAK cells.

\section{D-HORMONAL ENHANCEMENT OF GML}

Substance $P$ (Peninsula Labs, San Carlos, CA) was added to the tissue flasks simuitaneously with induction of $\mathrm{LAK}$ activity. $\mathrm{A}$ concentration of $10^{-5} \mathrm{M}$ was selected after going through the following determinations: in the gastrointestunal tract, concentrations as low as $10^{-10} \mathrm{M}$ exert a physiologic effect. 45 This concentration was therefore used as the starting point and was increased until a response was obtained. $10^{-5} \mathrm{M}$ therefore represents the threshold dose in the dose-response curve; it was selected over a higher dose because it is already pharmacological. Other in vitro studies using Substance $P$ as an immunomodulator used concentrations ranging between $10^{-10} \mathrm{M}$ and $10^{-6} \mathrm{M} .11$ 


\section{E-ISOLATION OF FRESH COLORECTAL CANCER CELLS}

The procedure is a combination of the methods of Brattain et al. ${ }^{50}$ and Keder et al. ${ }^{51}$ Non-necrotic malignant tissue was washed in CMF-IIBSS and minced in $3-5 \mathrm{~mm}$ fragments. The fragments were placed in an enzymatic solution containing hyaluronidase $(0.5$ $\mathrm{mg} / \mathrm{ml}$, Sigma), collagenase and DNAase $(2 \mathrm{mg} / \mathrm{ml}$ and $0.6 \mathrm{mg} / \mathrm{ml}$ respectively, Worthington). This digestion process was repeated approximatcly 5 times for successive periods of $45 \mathrm{~min}$. The cell suspension from the first digestion period was discarded to reduce/eliminate contamination with red blood cells, dead cells and debris. The cells were then collected by centrifugation and further purified over a $20 \%$ Percoll gradient (Pharmacia). The cells isolated were usually $85-9(1 \%$ viable (verified by microscopy) and were either used immediately or frozen in liquid nitrogen.

\section{F-TARGET CELL LINES}

Several target cell lines were used for cytotoxicity assays. Daudi is a lymphoid cell line used as a LAK sensitive internal control. The cultured human colorectal cell line HT-29 was maintained in duplicate in a solution of RPMI-1640 supplemented with $10 \%$ fetal calf serum (FCS; GIBCO) and 1\% PSF and split every third day. It is known to be slightly LAK sensitive and was used as one of the experimental targets. ${ }^{36}$ Fresh colon cancer cells isolated from human surgical specimens were used as the other experimental target.

\section{G-RADIOACTIVE LABELING OFTARGET CELL LINES}

Target cells were labeled by incubation with Chromium 51 $\left({ }^{51} \mathrm{Cr}\right)$. Three to five $X 10^{6}$ cells were harvested and pelleted by centrifugation $(1700 \mathrm{rpm} \times 5 \mathrm{~min}$.). All but $2 \mathrm{ml}$ of supernatant was aspirated and $200 \mu \mathrm{Ci}$ of sodium chromate $\left({ }^{51} \mathrm{Cr}\right.$; ICN Chemicals) was added. 
The cells were incubated at $37^{\circ} \mathrm{C}$ for $90 \mathrm{~min}$. and agitated periodically. In the case of adherent targets (HT-29), the cells were aliquoted in flat bottom microtiter plates at a concentration of $10^{4}$ cells $/ 0.2 \mathrm{ml} /$ well and incubated overnight in a $5 \% \mathrm{CO}_{2}-95 \%$ humidified air atmosphere to allow adherence. The next day, each well was washed 3 times immediately prior to the cytotoxicity assay. For suspended targets (Daudi, fresh cancer cells), the cells were washed 3 times and aliquoted in a round bottom microtiter plate at a concentration of $10^{4} \mathrm{cells} / 0.2 \mathrm{ml} / \mathrm{well}$ at the time of the assay.

\section{H-MICROCYTOTOXICITY ASSAY FOR LAK CELL ACTIVITY}

Effector LAK cells, cultured with or without substance $P$, were added in triplicate to the wells containing target cells. For flat bottom plates, a volume of $0.2 \mathrm{ml} /$ well was used and for round bottom plates, a volume of $0.1 \mathrm{ml} /$ well was used. Various effector to target $(E: T)$ ratios $(5: 1,10: 1,25: 1,50: 1)$ were obtained by serial dilution of the effector cells added to a fixed number $\left(10^{4}\right)$ of $51 \mathrm{Cr}$-labeled target cells/well. Spontaneous and maximal release were determined respectively by addition of culture medium and $1 \%$ sodium dodecyl sulfate (SDS, Sigma). Microtiter plates were centrifuged at $500 \mathrm{rpm}$ for $3 \mathrm{~min}$ and incubated at $37^{\circ} \mathrm{C}$ in a $5 \% \mathrm{CO}_{2}-95 \%$ humidified atr atmosphere for 4 hours. Following incubation, plates were spun again at $1000 \mathrm{rpm}$ for $5 \mathrm{~min}, 0.1 \mathrm{ml}$ of supernatant was aspirated from each well, and radioactivity was measured as counts per minute (cpm) i.l a Gamma counter. Cytotoxicity was expressed as \% specific ${ }^{51} \mathrm{Cr}$ relcase using the following formula:

$\%$ specific release $=$ experimental $\mathrm{cpm}-$ spontaneous $\mathrm{cpm} \times 100$ maximum cpm - spontaneous cpm

All statistical analyses were done using a two-tailed, unpaired student's t-test and differences were considered significant if $\mathrm{p}<0.05$. 


\section{RESULTS}

\section{A) LAK COMPARED TO LAK + SP AGAINST HT-29}

The cytotoxicity of LAK cells alone was compared to the cytotoxicity of LAK cells cultured with Substance P (SP) against the colon cancer cell line in culture IIT-29. For the control group (LAK cells alone), we did 7 assays. The mean age of the patients from whom the lymphocytes were obtained was 62 years. There were 3 males and 4 females. Four patients had colon cancer, 1 had diverticular disease, 1 had unexplained lower gastrointestinal bleeding and 1 had multiple colonic polyps. In the experimental group (LAK cells + SP), 11 assays were done. Patients' mean age was 60 years, there were 4 males and 7 females. The indication for surgery was: colon cancer in 6 patients, diverticular disease in 2 , multiple polyps in 2 and Crohn's disease in 1. Trudel et al. 36 have characterized the effect of LAK cells alone against HT-29. We repeated these experiments and obtained similar results (Fig. 1). When we repeated the experiments with LAK cells cultured in the presence of substance $P\left(10^{-5} \mathrm{M}\right)$, we obtained the following results: the cultured colon carcmoma cell line HT-29 showed the same susceptibility to lysis by LAK cells cultured with substance $P$ as it had to LAK cells alone (fig. 1). There was no statistical difference in the degree of cytotoxicity against HT-29 of LAK cells alone compared to LAK cells cultured with $S P(p=0.15)$ (Fig. 2). There was also no significant difference across the 2 groups between patients' age, sex, indication for bowel resection, Duke's stage of the disease and histological grade of the lumor. 


\section{FIGURE 1}

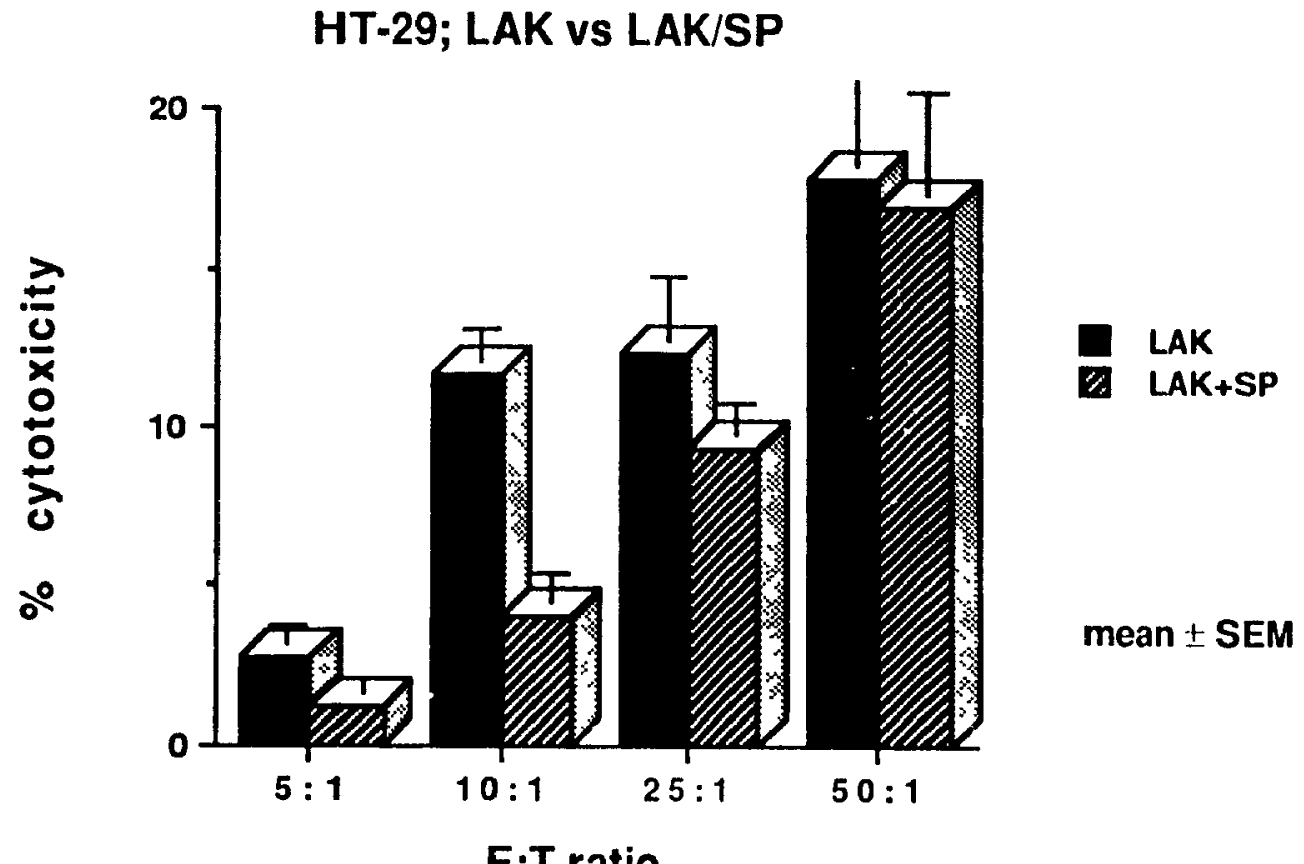

FIGURE 2

HT-29; LAK vS LAK+SP

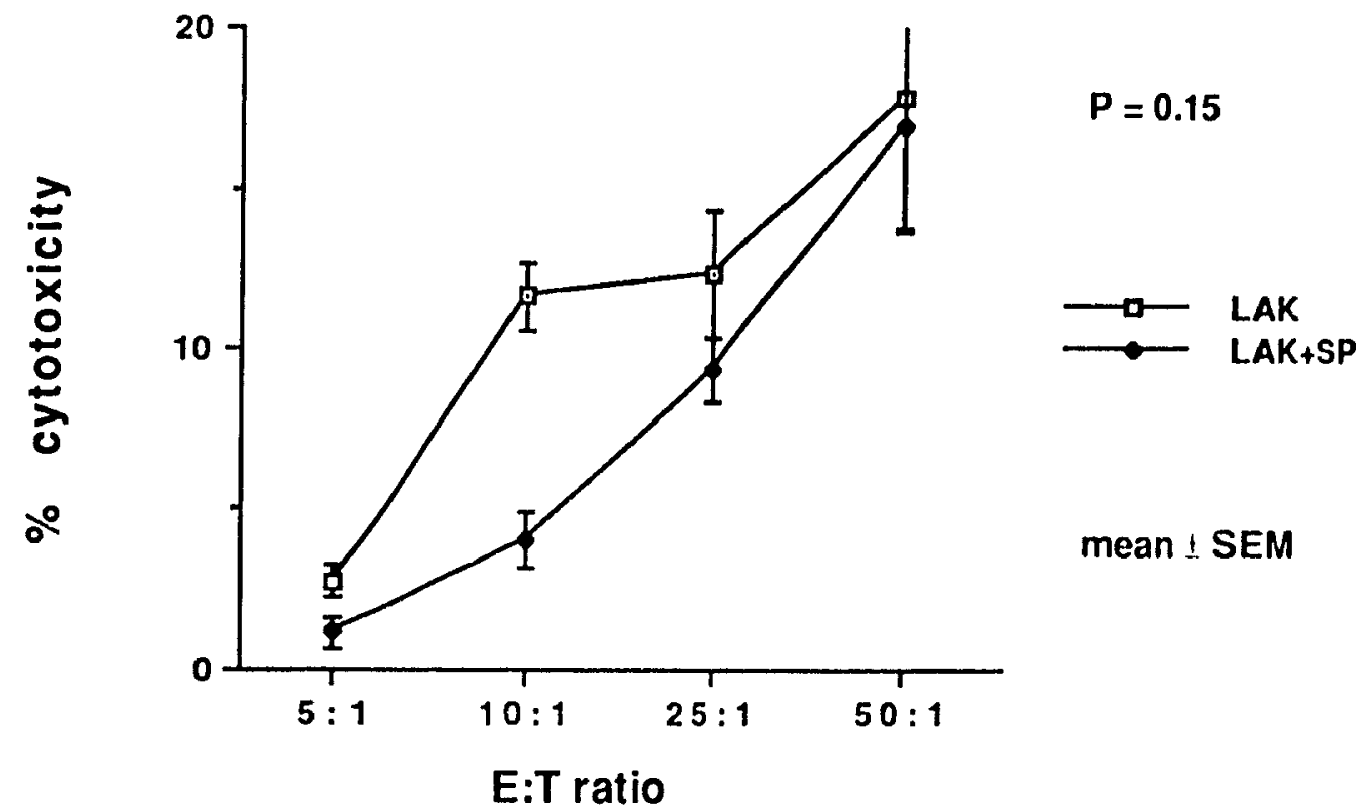


B) LAK COMPARED TOLAK + SP AGAINST FRESH COLON CANCER

The cytotoxicity of LAK cells alone was compared to that of LAK cells cultured with Substance $P$ (SP) against fresh colon cancer cells. In the control group (LAK cells alone), 8 assays were done. There were 3 males, 5 females and their mean age was 63 years. Surgical indications were: 6 carcinomas of the colon, 1 Crohn's discase and 1 diverticular disease. In the experimental group (LAK cells + SP), 11 assays were done. Five patients were males 6 females and their mean age was 59 years. Seven underwent surgery for colorectal cancer, 2 for diverticular disease, 1 for multiple colonic polyps and 1 for Crohn's disease. As Trudel et al. 18 had shown, we found fresh colon cancer cells to be completely resistant to LAK cells alone (fig. 3). In contrast, fresh colon cancer cells were lysed by LAK cells cultured with substance $P$ in a dose-responsive fashion (fig. 3). At each effector to target (E:T) ratio studied, there was a statistically significant difference in the cytotoxicity of LAK cells cultured with SP compared to LAK cells alone $(p<0.01)$ (Fig.4). The results obtained are independent of the age and sex of patients and of the clinical indication for bowel resection. These results are also independent of the Duke's stage of the disease, of the histological classification of the malignancy and of the autologous or allogenic nature of the effector cells. To control for the possibility that substance $P$ itself could be the lethal agent, we performed 3 assays where the effector was substance $P$ alone with culture medium. When tested against fresh colon cancer cells in the same type of cytotoxicity assay as described above, there was no lysis of the fresh cancer cells by substance $P$. 


\section{FIGURE 3}

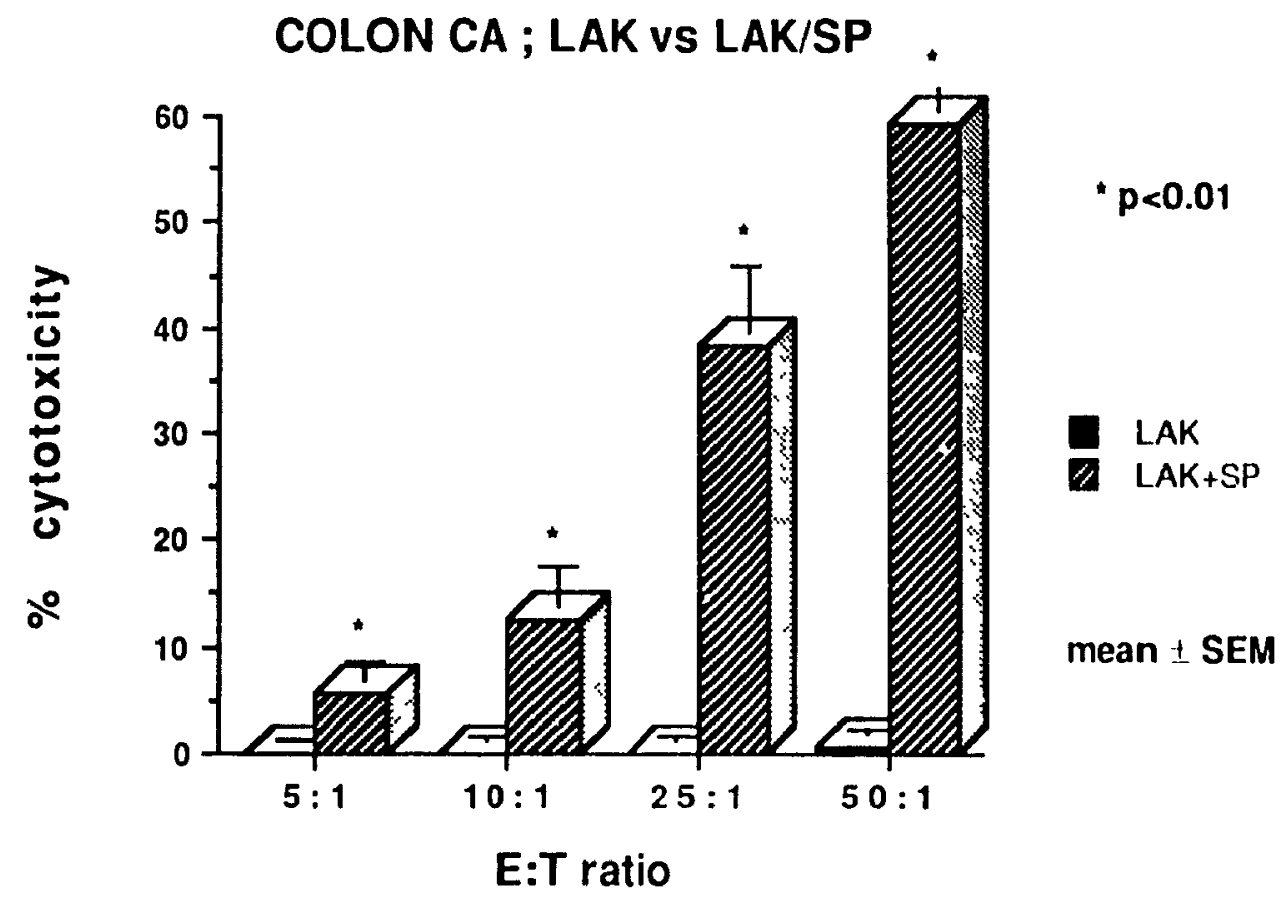

\section{FIGURE 4}

COLON CA; LAK VS LAK + SP

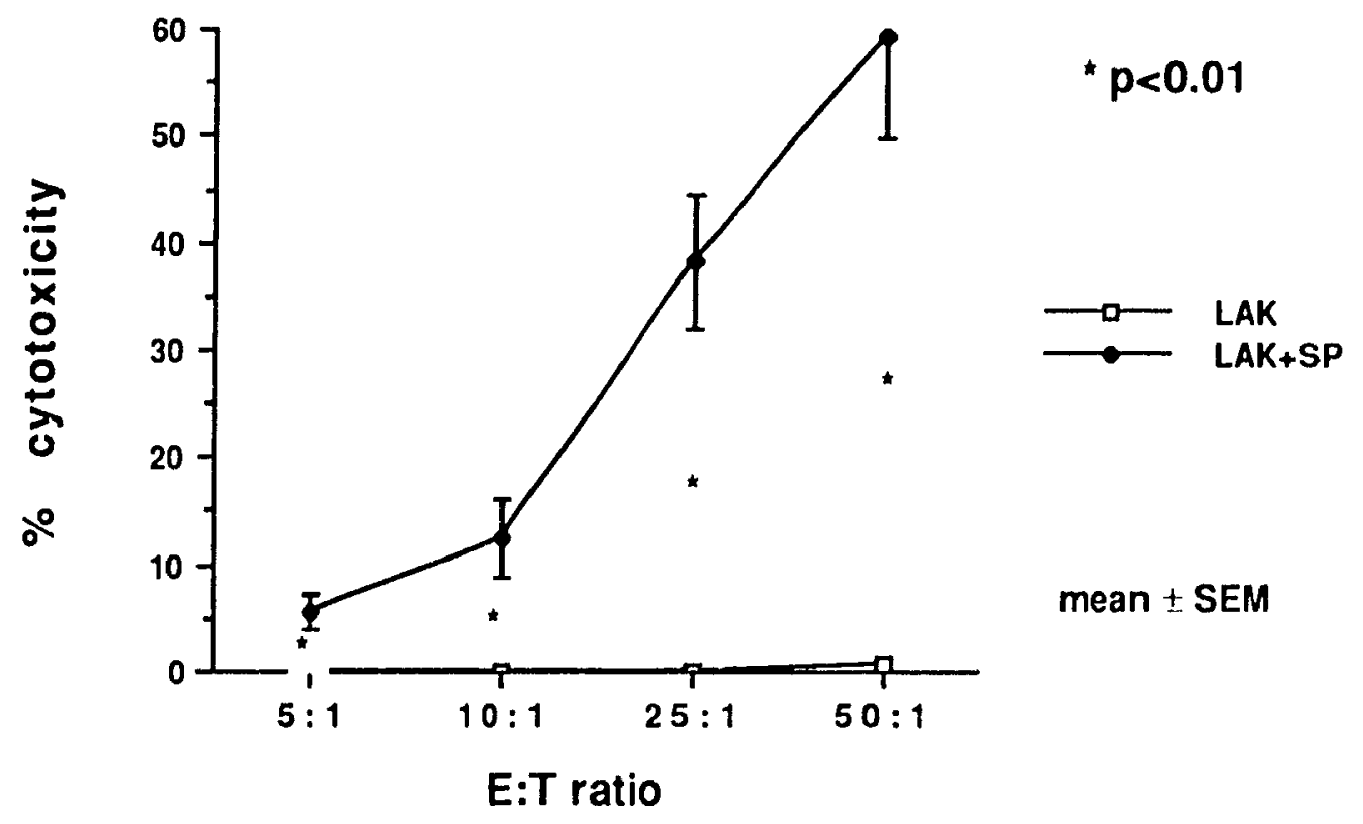


C) COMPARISON OF ACTIVITY OF LAK + SP AGAINST HT-29 AND FRESH COLON CANCER CELLLS

The difference in the degree of cytotoxicity of LAK cells cultured with Substance P (SP) against fresh and cultured targets was compared. LAK cells cultured with SP exhibited a stronger degrec of cytotoxicity toward fresh colon cancer cells than they did against the cultured colon cancer cells HT-29. At higher E:T ratios $(25: 1,50: 1)$, the difference was statistically significant $(\mathrm{p}<0.01)$ (Figs. $5 \& 6)$. 


\section{FIGURE 5}

LAK+SP: HT-29 vs Colon CA

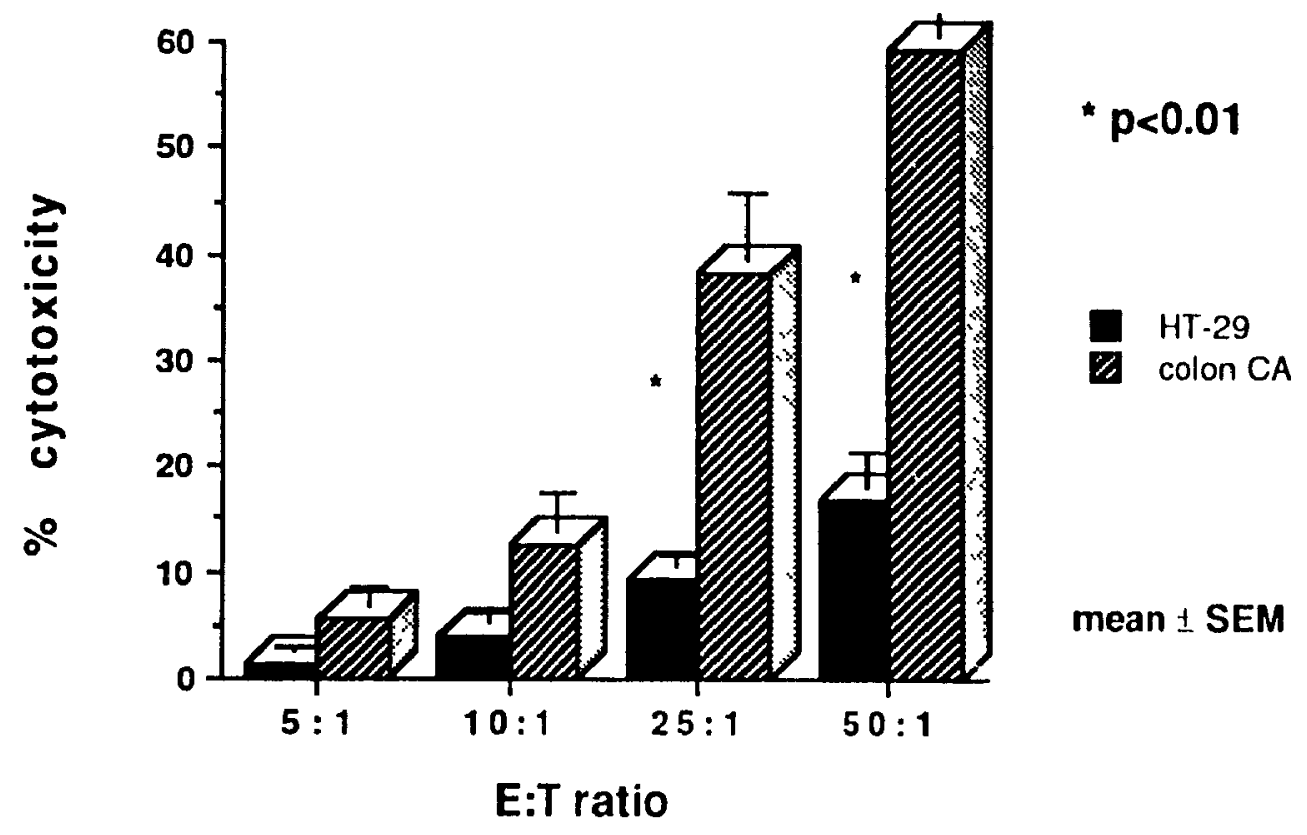

FIGURE 6

LAK + SP: HT-29 vs COLON CA

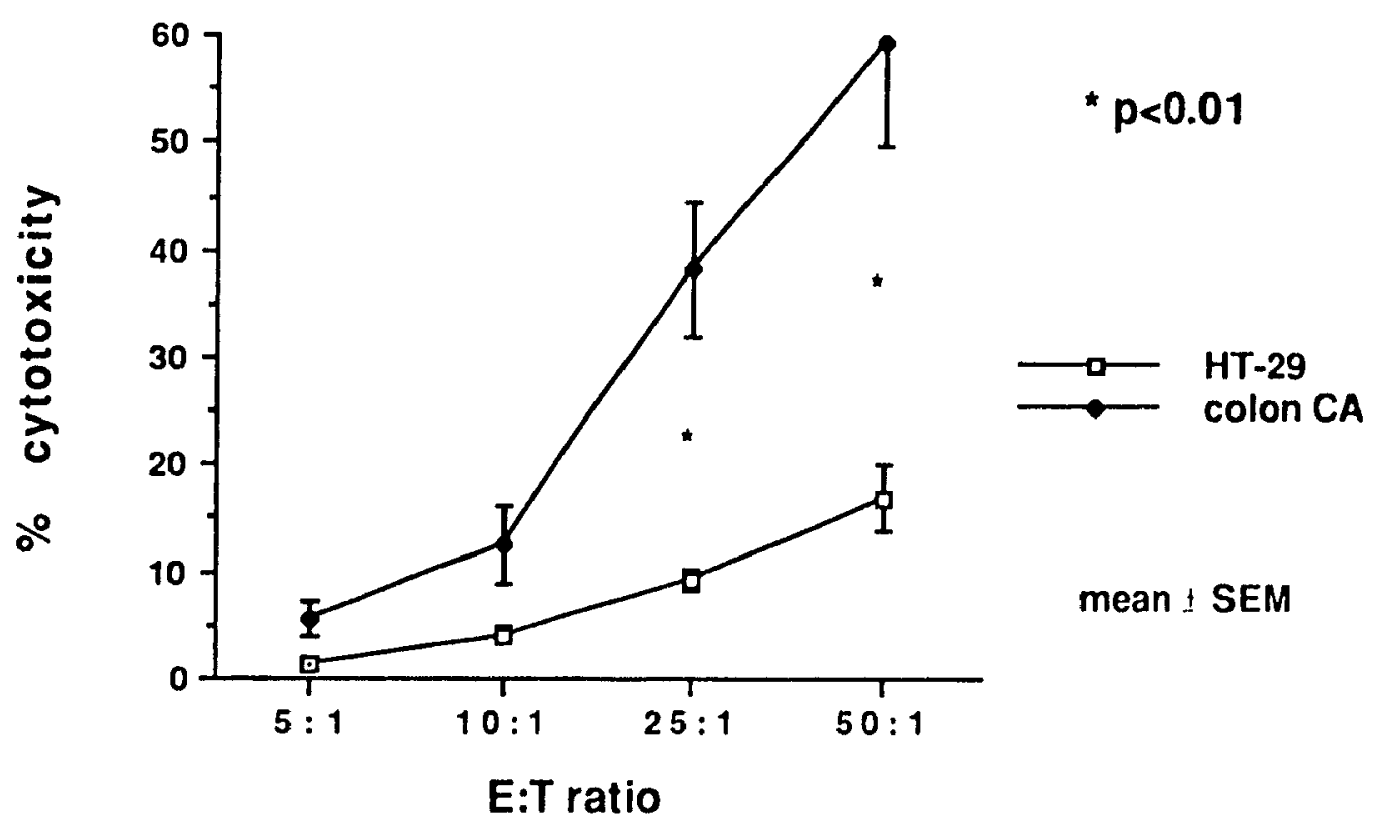


DISCUSSION

The results of this study suggest that the gut mucosal immune system can be modulated by substance $P$. The net effect of this modulation results in an increase in gut-derived LAK cell cytotoxicity against fresh colon cancer cells, but not against the cultured human colon cancer cell line HT-29.

The mechanism for modulation is uncertain at this time. Previous reports have demonstrated specific stimulation of human peripheral blood T-lymphocyles by Substance P. 42,43,45 Other reports have demonstrated a stimulatory effect of SP on human thymus 52, and on hisnan $B$ lymphocytes 53. Animal studies have also reported a modulatory effect of $\mathrm{SP}$ on the immune system: Moore et al. have worked on lymph nodes of sheep 54,55 and demonstrated an increase in CD4 cells mediated by SP. Croitoru et al. have done experiments with murine intestinal lymphocytes. They have shown an increase in the natural killer activity modulated by SP 56 .

In addition to these several studies that demonstrated a stimulatory effect of SP on a number of lymphocyte subsets, the presence of high-affinity receptors for SP on lymphocytes has been suggested.41,45,57 This body of information led to the hypothesis that SP exerts its effect on lymphocytes via a direct hormonereceptor interaction. This theory is supported by the fact that an antagonist of SP; the peptide [D-Pro ${ }^{2}, \mathrm{D}-\mathrm{Phe}^{7}, \mathrm{D}-\mathrm{Tr} \mathrm{P}^{9}$ ]-SP inhibits the proliferative effect of $S P$ on human peripheral blood lymphocytes by a competitive mechanism. ${ }^{14}$ This antagonist was first characterized as such when it was found to inhibit the SP-induced contraction of guinea pig ileal smooth muscle.58,59

In summary, so far, the literature is capable of supporting the theory of a receptor-mediated stimulatory effect of Substance $P$ on human peripheral blood lymphocytes. However we have done a series of experiments using intestinal lymphocytes, not peripheral blood lymphocytes. To determine if the modulatory effect of SP on this particular subset of immune cells is also receptor-mediated, we are currently conducting a series of experiments whereby a group of 
LAK cells are cultured with substance $P$ alone and a second group of LAK cells is cultured with substance $P$ and its antagonist. If the results of this experiment show competitive inhibition, we will have demonstrated that the effect of substance $P$ on intestinal lymphocytes is also receptor-mediated.

Our results showed increased LAK cell activity by hormonal manipulation with SP against a fresh but not against a cultured target. Why do fresh cancer cells and cultured cells respond differently to the same effector cells? To our knowledge there has been no work done on the effect of neuropeptides such as substance $P$ on colorectal cancer. We do not know if there is a specific SP receptor on colon cancer cells. Should there be a specific SP receptor on human colon cancer, the presence of SP in the culture medium could improve the stereotaxic interaction between the effector and its target. Substance $P$ receptors might be down-regulated on cells kept in culture for extended periods, which would prevent the improved interaction to take place. We are presently culturing the HT-29 target cell line with Substance $P$ in order to perhaps upregulate $S P$ receptors in these cells. We will then repeat the microcytotoxicity assays with LAK cells + SP against IIT-29 + SP. This should help to determine the mechanism of action of SP and its interactions with target cells.

In summary we have demonstrated an enlancing effect of Substance $P$ on gut-derived cytotoxicity against fresh colon cancer cells. From these first experiments we conclude that the hypothesis of hormonally manipulating the gut mucosal immune system is viable. Previous work has shown a receptor-mediated effect of SP on peripheral blood lymphocytes but not on intestinal lymphocytes. We need to do additional work to determine if the effect of SP on the LPMC is also receptor-mediated by using SP's antagonist. We need, in light of the results we obtained, to do a series of assays using peripheral blood lymphocytes of patients with colon cancer. Should we observe similar findings, blood lymphocytes represent a more accessible source of cells when clinical application is 
considered. We also need to characterize the way LPMC enhanced by SP interact with their target in order to explain the different results observed in fresh and cultured colon cancer cells. 


\section{BIBLIOGRAPHY}

1- Silverman A, Desai TK, Luk JD. Colorectal Cancer. Scope of the problem. Gl Clinics of North America 17(4):655, 1988.

2- Bowman DL, Weaver DW. Colon Cancer: Surgical Therapy. GI Clinics of North America 17(4):859, 1988.

3- Herskovic A, Han I. The role of Radiation in the distal bowel. GI Clinics of North America 17(4):887, 1988.

4- Cass AW, Million RR, Pfaff WW. Patterns of recurrence following surgery alone for adenocarcinoma of the colon and rectum. Int J Radiat Oncol Biol Phys 4:801, 1978.

5- Poplin E, Baker L. Colon Cancer: Medical Therapy. GI Clinics of North America 17(4):873, 1988

6- Nelson RL. What is new in colorectal surgery. ACS Bulletin 76:1: 12, 1991 .

7- Wadler S. The role of immunotherapy in Colorectal Cancer. Seminars in Oncology. (Suppl 1)18(1):27, 1991.

8- Conteas CN, Desai TK. Relationship of hormones and growth factors to colon cancer. GI Clinics of North America 17(4):761, 1988 .

9- Gibson UFC, Jordan VC. Adjuvant Antiestrogen Therapy for Breast Cancer. Past, Present, and Future. Surgical Clinics of North America 70(5):1103, 1990.

10- Furr BJA, Jordan VC. The pharmacology and clinical uses of tamoxifen. Pharmacol Ther 35:127, 1984.

11- Delozier T, Julies J-P, Juret P, et al: Adjuvant tamoxifen in post-menopausal breast cancer: Preliminary results of a randomized trial. Breast Cancer kes Treat 7:105, 1986.

12- McConnell JD. Physiologic Basis of Endocrine Therapy for Prostatic Cancer. Urologic Clinics of North America 18(1):1, 1991. 
13- Trachtenberg J, Walsh PC. Correlation of prostatic nuclear androgen receptor content with duration of response and survival following hormonal therapy in advanced prostatic cancer. J Urol 127:466, 1982.

14- Van Aubel O, Bolt-de-Vries J, Blankensrein MA, et al: Prediction of time to progression after orchiectomy by the nuclear androgen receptor content from multiple biopsy specimens in patients with advanced prostate cancer. Prostate 12:191, 1988.

15- Sirinck KR, Levine BA, Moyer MP: Pentagastrin stimulates in vitro growth of normal and malignant human colon epithelial cells. Am J Surg 149:35, 1985.

16- Rae-Venter B, Townsend CM Jr, Thompson JC, et al: Gastrin receptors in cultured human cells derived from carcinoma of the colon, stomach and pancreas. Endocrinology 180 (suppl)A: $153,1981$.

17- Van Healst-Pisani CM, Pisani RJ, Kovach JS. Cancer Immunotherapy: Current status of treatment with Interleukin2 and Lymphokine-activated-killer cells. Mayo Clinic Proc. $64: 451,1989$.

18- Greenberg PD, Klarnet JP, Kerr DE, Chuver MA. Therapy of dissemiliated tumors by adoptive transfer of specifically immune cells. Prog. Exp.Tumor Res. 32:104, 1988.

19- Fidler AJ, Jessup JM, Fogler WE. et al. Activation of tumoricidal propertics in peripheral blood monocytes of patients with colorectal carcinoma. Cancer Research. 46:994, 1986.

20- Hanna MG Jr, Hoover HC Jr, Peters LC, et al: Fundamental applied aspects of successful active specific immunotherapy of cancer, in Oldham RK (ed): Principles of Cancer Biotherapy. New York, NY, Raven, 1987, pp 195-221.

21- Rosenberg S. LAK cells: A new approach to immunotherapy of cancer. J. ef Clin. Invest. 75:4, 1985. 
22- Terry WD, Rosenberg SA. eds. Immunotherapy of human cancers. New York: Elsevier/North Holland. 1982.

23- Hollinshead A, Elias EG, Arlen M, et al: Update on Phase 1 specific active immunotherapy colon cancer trial: Humoral/ cellular specific immunity studies. Proc Am Soc Clin Oncol 9:120, 1990.

24- Goldberg SM, Nivatvongs S, Rothenberger DA: Colon, Rectum and Anus, in Schwartz, (ed): Principles of Surgery. McGrawHill, 1989, pp 1225-131 4 .

25- Mule JJ, Shu S. Schwarz SL, Rosenberg SA: Adoptive immunotherapy of established pulmonary metastases with LAK cells and recombinant Interleukin-2. Science $225: 1487,1984$.

26- Mule JJ, Shu S, Rosenberg SA: The anti-tumor efficicy of lymphokine-activated-killer cells and recombinart interleukin-2 in vivo. J Immunol 135:646, 1985.

27- Lafreniere R, Rosenberg SA: Successful Immunotherapy of murine experimental hepatic metastases with lymphokineactivated-killer cells and recombinant interleukin-2. Cancer Res 45:3735, 1985.

28- Lotze MT, Chang AE, Rosenberg SA, et al: IIigh-dose recombinant interleukin-2 in the treatment of patients with disseminated cancer: responses, treatment-related morbidity, and histologic findings. JAM $A$ 256: 3117, 1986.

29- NCI to open more LAK/IL-2 cancer center programs. Clin Cancer Lett 10:2, 1987.

30- Rosenberg SA, Lotze MT. et al. A Progress report on the treatment of 157 patients with advanced cancer using LAK cells and IL-2 or high dose IL-2 alone. NEJM 316 (15) 889, 1987.

31- Duchter JP. LAK cells / Tumor-infiltrating-lymphocytes therapy: Efficacy, Toxicities, Controversies. J. Clin. Apheresis. $5: 80,1990$. 
32- Nishimura T, Yagi H. Generation of LAK cells from tumorinfiltrating lymphocytes. Cellular Immunology. 100:149, 1986.

33- Grimm EA. Human LAK cells as a potential immunotherapeutic modality. Biochemica and Biophysica Acta. 865:267, 1986.

34- Guillou P. IL-2 and LAK cell therapy for gastrointestinal cancer. Acta Chir. Scand. 549(Suppl):26, 1989.

35- Marshall GD. Adoptive immunotherapy in GI malignancies using IL-2. Current results and future prospects. Acta Chir. Scand. 549(Suppl):71, 1989.

36- Trudel JL, Fazio V, Fiocchi C, et. al. LAK cells from human intestinal mucosa: Cytotoxicity against tumor cell lines and modified self but not autologous and allogenic colon cancer cells. J. of Surgical Research. 44:445, 1988.

37- O'Dorisio MS. Neuropeptides and gastrointestinal immunity. Am. J. Med. 81:74, 1986.

38- Blalock JE, Harbour-Mcmenarnine D, Smith EM. Peptide Hormones shared by the neuroendocrine and immunologic systems. J. immunology 135:8585, 1985.

39- Pawlikowsky M, Stepien H, Kunert-Radek J, Schally AV. Effect of somatostatin on the proliferation of mouse spleen lymphocytes in vitro. Biochem., Biophys. Res. Comm.129(1): $52,1935$.

40- Foris G, Gyimesi E, Komaromi I. The mechanism of antibodydependant cellular cytotoxicity stimulation by somatostatin in rat peritoneal macrophages. Cellular Immunology. 90:217, 1985 .

41- Payan DG, Brewster DR, Goetzel EJ. Specific stimulation of human $\mathrm{T}$ lymphocytes by Substance P. J. Immunol. 131:1613, 1983. 
42- Nordlind K, Miutt V. Modulating effects of B-endorphin, somatostatin, substance $P$ and vasoactive peptide on the proliferative response of peripheral blood $T$ lymphocytes of nickel allergic patients to nickel sulfate. Int. Archs Allergy Appl. Immun. 81:368, 1986.

43- Nordlind K, Mutt V. Influence of B-endorphn, somatostatin, substance $P$ and vasoactive intestinal peptide on the proliferative response of human peripheral blood $\mathrm{T}$ lymphocytes to mercuric chloride. Int. Archs Allergy Appl. Immun. 80:326, 1986.

44- Van Epps DE, Saland L. B-endorphin and met-enkephalin stimulates human peripheral blood mononuclear cell chemotaxis. J. Immunol. 132:3026, 1984.

45- Payan DG, Brewster DR, Missirian-Bastian A, Goetzel EJ. Substance $P$ recognition by a subset of human $T$ lymphocytes. J. Clin. Invest. 74:1532, 1984.

46- Bathena SJ, Louie J, Schecter GPP, Redman RS, Wahl L, Recant L. Identification of human mononuclear leukocytes bearing receptors for somatostatin and glucagon. Diabetes 30:127, 1981.

47- Smith EM, Harbour-McManamin D, Blalock JE. Lymphocyte production of endorphins and endorphin-mediated immunoregulatory activity. J. Immunol. 135:7795, 1985.

48- Fiocchi C, Battisto JR, Farmer RG. Gut mucosal lymphocytes in inflammatory bowel disease. Isolation and preliminary functional characterization. Dig. Dis. Scı. 24:705, 1979.

49- Bull DM, Bookman MA. Isolation and functional characterization of human intestinal mucosa lymphoid cells. J. Clin. Invest. 59:966, 1977.

50- Brattain MG, Kimball PM, Pretlow TG, et al. Partial purification of human colonic carcinoma cells by sedimentation. Br. J. Cancer. 35:850, 1977. 
51-Keder E, Ikejri BL, Bonnard GD, et al. A rapid technique for isolation of viable tumor cells from solid tumors: use of tumor cells for induction and measurement of cell-mediated cytotoxic responses. Eur. J. Clin. Oncol. 18:991, 1982.

52- Piantelli M, Maggiano N, Larocca LM, Ricci R, Ranalletti FO, Lauriola L, Capelli A. Neuropeptide-immunoreactive cells in human thymus. Brain Behav. Immun. 4:189, 1990.

53- Laurenzi MA, Persson MA, Dalsgaard CJ, Ringd O. Stimulation of human $B$ lymphocyte proliferation by the neuropeptides substance $P$ and neurokinin A. Scand. J. Immunol. 30:695, 1989.

54- Moore TC, Whitley GA, Lami JL, Said SI. Substance P increases and prolongs increased output of T4 (CD4) lymphocytes from lymph nodes of sheep in vivo: is it a mediator of immunological memory? Immunopharmacology. 20:207, 1990.

55- Moore TC, Lami JL, Spruck CH. Substance P increases lymphocyte traffic and lymph flow through peripheral lymph nodes of sheep. Immunology 67:109, 1989.

56- Croitoru K, Ernst PB, Bienenstock J, Padol I, Stanisz AM.

Selective modulation of the natural killer activity of murine intestinal leukocytes by the neuropeptide substance P. Immunology 71:196, 1990.

57- Pascual DW, Blalock JE, Bost KL. Antipeptide antibodies that recognize a lymphocyte substance $P$ receptor. J. Immunol. $143: 3697,1989$.

58- Hanley MR. Substance $P$ antagonists. Trends Neurosci. 5:138, 1982.

59- Folkers K, Horig J, Rosell S, Bjorkroth U. Chemical design of antagonists of Substance P. Acta Physiol. Scand. 111:505, 1981 .

60- Consensus Statement. Adjuvant therapy for patients with colon and rectum cancer. NIH Consensus Development Conference. $8: 4,1990$. 